\title{
Trends in Breeding New Olive Varieties in Israel for Quality and Economic Management
}

\author{
Shimon Lavee ${ }^{1,2 *}$, Benyamin Avidan', Giora Ben-Ari ${ }^{1}$ \\ ${ }^{1}$ Institute of Horticulture, Volcani Center, ARO, Bet-Dagan, Israel \\ ${ }^{2}$ Institute of Plant Science Faculty of Agriculture, Hebrew University of Jerusalem, Rehovot, Israel \\ Email: ${ }^{\text {lavee@agri.huji.ac.il }}$
}

Received 1 May 2014; revised 27 June 2014; accepted 14 July 2014

Copyright (C) 2014 by authors and Scientific Research Publishing Inc.

This work is licensed under the Creative Commons Attribution International License (CC BY). http://creativecommons.org/licenses/by/4.0/

cC) (i) Open Access

\section{Abstract}

The domesticated olives originated based on decades of selection from the natural forest around the Mediterranean basin being one of the oldest cultivated tree crops. The requirement for new olive varieties increased markedly during the last $\mathbf{1 0 0}$ years as a result of a worldwide transformation changing from a traditional extensive to a modern intensive mechanized industry. The traditional olive cultivars still widely used are selections from the local autochthonous cultivars which are well adapted to their natural environment. However, the level of production of those is usually rather low and many of them fail to respond enough to modern intensification methods. The wild olive population is gradually diminishing in all regions thus, natural selection is not efficient enough for developing the cultivars required for the new intensive olive industry. Cross breeding between cultivars with specific characters became the basis for the required new cultivars. The genetic diversity in progenies of most olive cultivars is extremely wide and thus becomes the basic source for breeding of the needed new cultivars. However, the genetic information on olive heredity and identification of specific gene characteristics is still limited. Genomic information is required for rational choice of genitors in accordance with each breeding aim, particularly as most criteria required for the new varieties are of multi-gene nature. The availability of advanced genomic information will also serve as basis for molecular engineering when accepted for use in the olive commodity. Geographically isolated olive populations developed during generations of inbreeding in remote regions are another important genetic resource of characters required for breeding the cultivars for the new modern mechanized olive orchards. The use of molecular markers based on AFLP, SSRs, DArT and SNPs is important for the choice of genitors leading to a reduction of the progeny size required in olive breeding. Presently the newly released olive cultivars are still the result of classical breeding.

\footnotetext{
${ }^{*}$ Corresponding author.
} 


\section{Keywords}

\section{Olive, Orchard Systems, Breeding, Genetic Markers New Cultivars}

\section{Some Notes on History and Tradition}

Selection of olive trees with suitable fruit for human consumption started at least 10,000 years ago while utilization of olive fruit by the ancient population is at least double as old. Breeding of olive varieties in those old days was based on selection of favorable types from the wild and vegetative propagation of the more favorable trees [1]. The initial domestication of the olive after identifying their value as sustainable food and a significant source of energy for human utilization was first identified by the population around the eastern end of the Mediterranean basin [2]-[4]. From there, the knowhow of olive fruit utilization, olive tree cultivation and the olive "culture" in general spread hand in hand with the civilization towards the west [5] (Figure 1). As olive trees were part of the natural forest around most parts of the Mediterranean basin, selection of favorable trees for agricultural utilization took place independently at most regions where the information on the benefit of the olive fruit spread and trade of olive products became significant all over the old world [6]. The benefit and importance of olive products and particularly of the olive oil established itself in the tradition and religion in those ancient times. Thus, local selection flourished all around the Mediterranean basin [7]-[10]. As a result of the wide scale of local tree selections and the traditional cultivation thereafter the major characteristics of the old olive industry are still prevailing and notable even in the commercial olive cultivation today.

The wide spread of olive tree selections around the Mediterranean basin had far reaching consequences on the nature and development of the olive industry. The independent selection of olive trees all around the Mediterranean basin resulted in a massive amount of localized cultivars most of which are well adapted and still cultivated but each on a small scale and in a limited region [11]. It is clear today that the various cultivated varieties are combinations with the specific Oleaster types in each region around the Mediterranean basin [10] [12]. This created a major problem in updating the olive industry to the economical standards required for a viable agricultural undertaking today. Although, horticultural techniques for olive growing were well developed already in ancient times, the application of modern science for the development and updating the olive commodity was limited up to the middle of the last century.

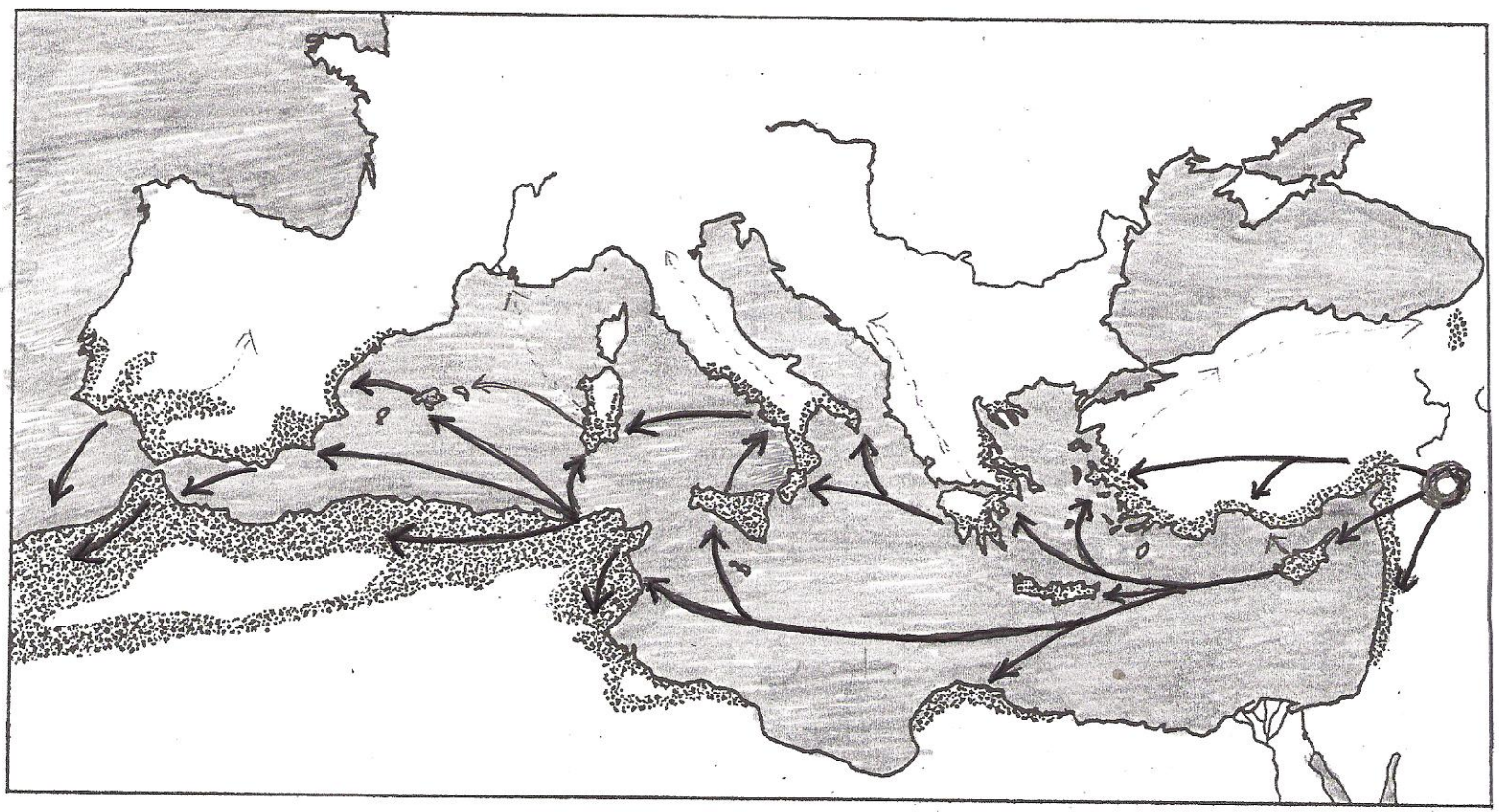

Figure 1. The initial distribution of olive "culture" in the Mediterranean basin. 


\section{Some Notes on the Trends Today's Industry}

In most traditional olive growing countries most of the olive growing area is still based on extensive cultivation using marginal land with no irrigation and little mechanization (Figure 2). Some of these orchards are undergoing intensification with emphasis on supplementary irrigation, harvest mechanization and modern plant protection aiming to increasing production efficiency and product quality. The techniques used are based on intensification studies started with table olives and are applied during the last 60 years also in the olive oil industry [13].

Presently, the world olive industry is undergoing a marked transformation adjusting to today's economical demands. The major changes to present are based on orchard intensification, advanced horticultural methodologies, mechanization, controlled management and new efficient industrial technologies (Figure 3). Lately it became apparent that intensification in general and particularly for new developing orchard systems new suitable cultivars is needed. While cultural techniques started to receive considerable attention already for some time, the need for standardization and improvement of plant material has been recognized only in recent years. Selection and breeding new olive cultivars in the past was a long tedious task. Based on a methodology developed to shortening significantly the juvenile period of olive seedlings [14] [15] breeding efforts of new cultivars are now devoted in many research centers towards developing and selection of new varieties more suitable for intensive cultivation of new modern olive orchards.

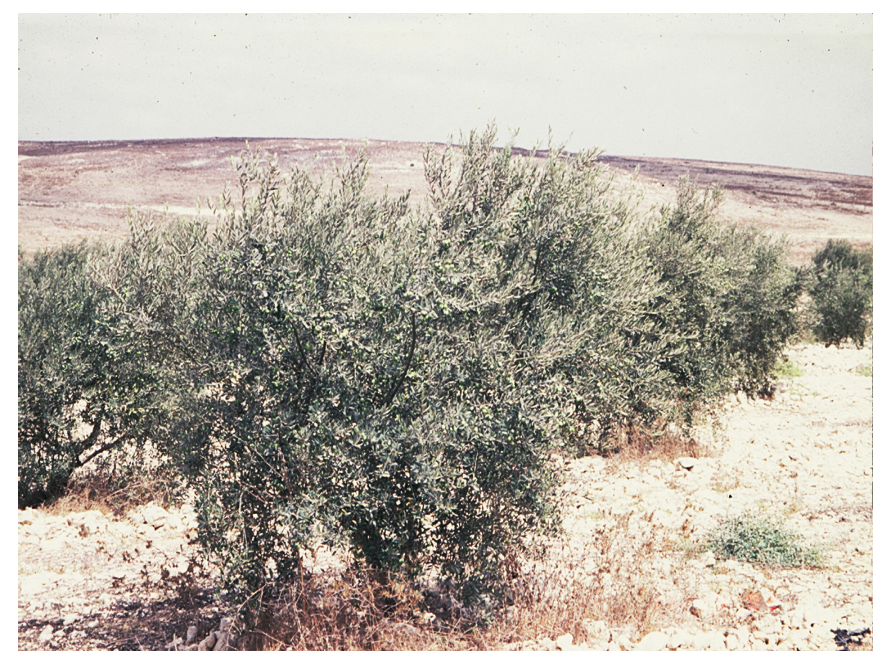

Figure 2. A traditional rain-fed orchard.

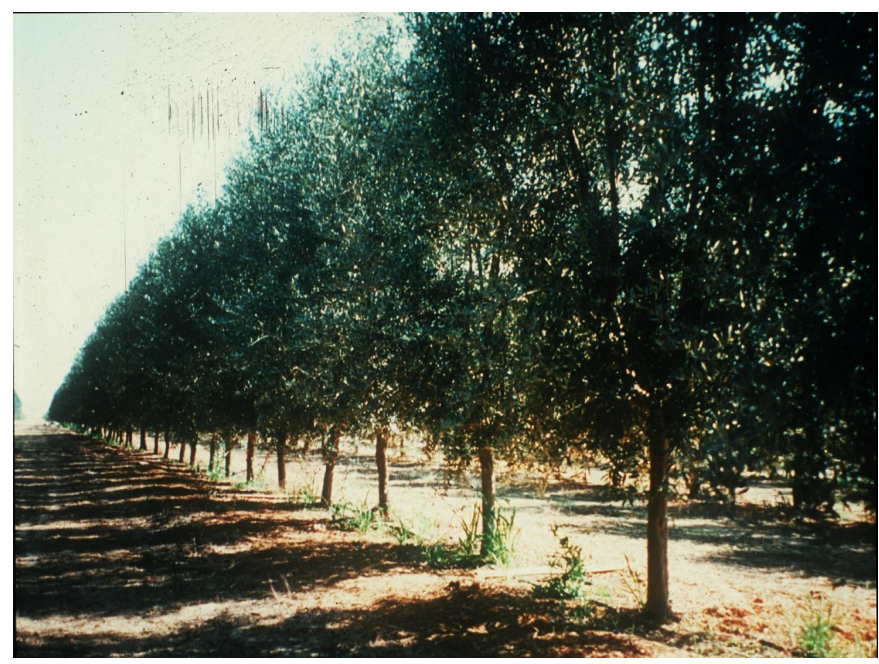

Figure 3. A modern irrigated orchard. 


\section{Selection and Breeding of New Plant Material}

The initial improvement of olive germplasm was still based on selection and identification of unique or outstanding individual trees propagated vegetatively and designated improved clones [16]-[18]. Some of those selections were even designated as new varieties (Figure 4). The initial efforts of breeding new olive varieties started about 50 years ago were still mostly based on classical cross breeding methods between commercial cultivars (Figure 5).

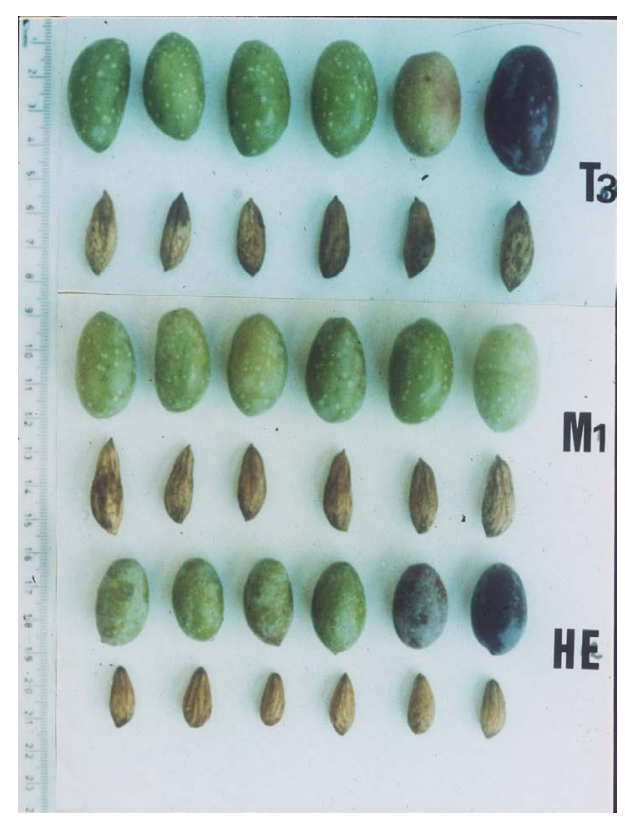

Figure 4. Clonal selection within a traditional large scale cultivar.

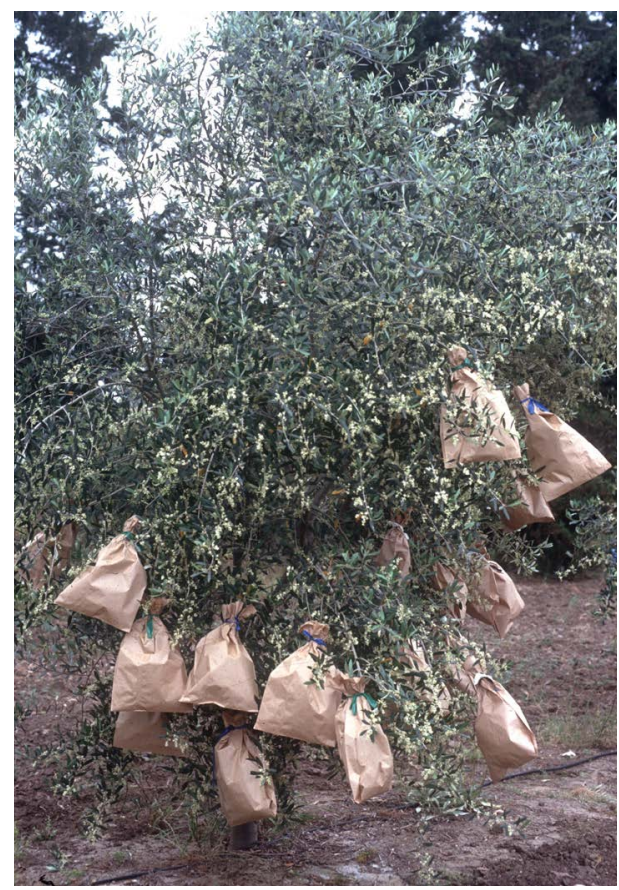

Figure 5. Classical cross breeding applied methodology. 
The breeding work increased considerably with the development of crossing systems, which could avoid emasculation of the female flowers. This was possible due to the low self fertilization at high temperatures within most olive cultivars [19]. As fruit set in olive flowers is relatively low, a reduction in the number crosses for the required selection progeny is a critical labor saving factor. Modern biochemical and molecular techniques such as enzyme isozyme variation, phenol composition [20] [21] and particularly molecular techniques for DNA characterization are critical for variety identity verification prior to directed crossing application (Figure 6). These methods were also applied for identifying population distribution [22] [23]. Comparing the autochthonous wild and cultivated populations in different Mediterranean countries revealed some genetic relations and specific characters shared among the tree population in each of the major growing regions [9] [10] [24]. This work was the beginning for recognizing the origin of cultivars and identity verification of various miss-defined cultivars distributed under either the same or different names. Furthermore, the accumulation of molecular information on cultivar origin as well as classical breeding results enabled to identify and accumulate specific genetic information [25], was still highly limited, on the species Olea europaea (Figure 6).

Although, the initially used randomized DNA multiplication method-PCR-RAPD—is a powerful tool for variety identification. It also needs in many cases morphological characterization to ensure varietal verification. More accurate identification could be achieved by using additional DNA molecular methodologies such as RFLP, AFLP and more recently micro-satellite loci SSR and SNP techniques [22] [26]-[29]. Determination of the genetic origin of known cultivars is critical for identifying specific gene-controlled traits within the olive resources in each of the different countries. One of the major problems in efficient olive breeding is the still limited genetic information of the Olea europaea species. With the present development of intensive breeding programs in various laboratories based on both classical and molecular approaches, a considerable amount of new genetic information is accumulating. In most new olive breeding programs presently major efforts are devoted to the identification of genetic markers, on basis of defined DNA loci and sequences [25] [30]. Identification of markers for specific genetic properties within various varieties is the basis for resources in future breeding and molecular cultivar "repair" (Figure 7). The recent enhanced use of the micro-satellite technique might enlighten the possibility that domestication of the Olea europaea involved selection for polyploidy. The identification of DNA sequences for specific properties can serve as a powerful tool for increasing the efficiency of cross breeding and genetic manipulation of locally adapted cultivars. Various physiological phenomena [31] [32]

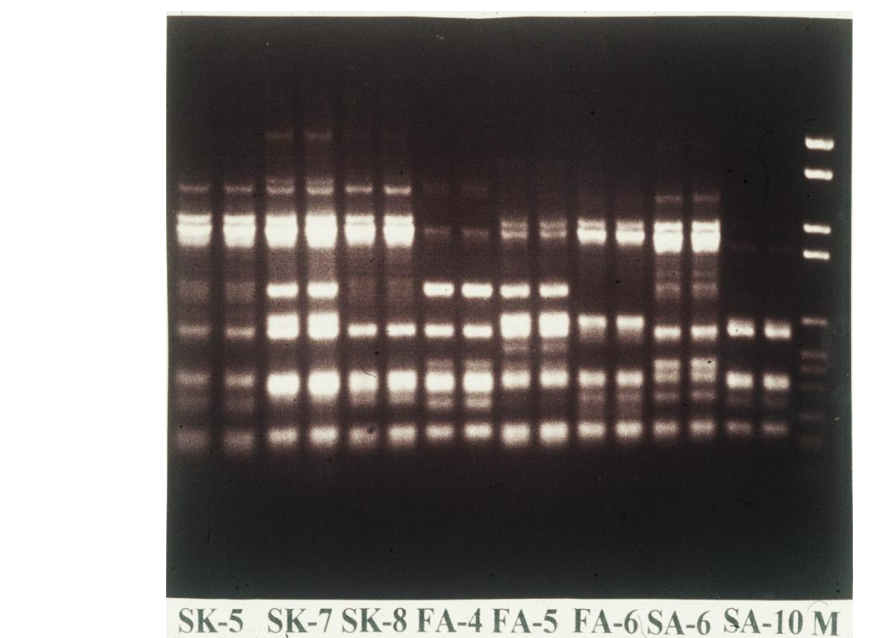

Figure 6. RAPD-PCR bands of eight cv. Nabali clones or new varieties.

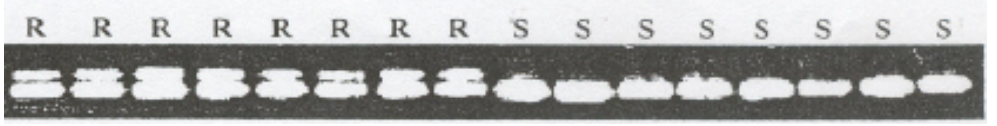

Figure 7. A DNA marker specific for resistance to Spilocaea oleagina. DNA samples were taken from resistance $(\mathrm{R})$ or susceptible $(\mathrm{S})$ tees. 
such as the length of the juvenile period, tree form and vigor, fruit form and ripening as well as oil accumulation are dominated in the olive by female heredity (Figure 8). Considerable advances were lately made in adopting molecular breeding methodology in Olea europaea. The controlled development of embriogenic calli to which molecular markers or modified genes could be introduced made it possible to achieve and select genetic manipulated plants (Figure 9). This methodology could be of most significant importance for modifying a single unfavorable character in a regional well adapted cultivar and the beginning to develop custom engineered plants for the future orchard. Still, this approach is presently banned for the olive industry.

The development of intensive olive orchards for oil involves the utilization of new orchard techniques and suitable responsive plant material. Orchard planning today has to be an integrated operation based on the local growing conditions, the desired intensification, suitable plant material and horticultural technology [13]. Adaptation of the orchard to modern mechanization demands a considerable amount of labor in canopy control and pruning. This is true for most types of intensive orchards though each newly developing orchard system might require basically different plant material [33]. The suitability of the genetic properties of the trees to each specific orchard system is critical for saving both manual labor and mechanical operations. Many growth characteristics, fruiting control and plant protection problems can be controlled by a large variety of different chemical and hormonal sprays or laborious mechanical treatments. The use of plant material with genetic adaptation to each of the various orchard systems and specific environmental conditions is the basis for optimal production and in the long run less costly. Thus, resistance to diseases and pests, controlled growth vigor, fruiting wood development and required tree form should be genetically controlled in the cultivars to be used (Figure 10). This is of particular importance in the presently developing hedge row orchards for the use of over head harvesters. Still, to present

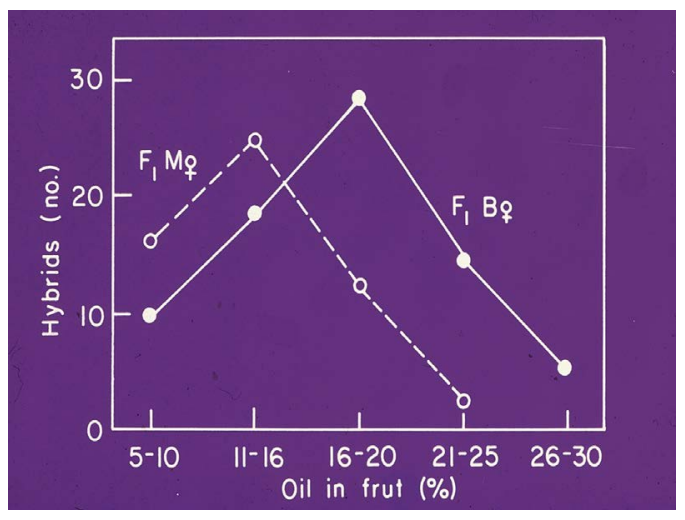

Figure 8. Dominance of female heredity in the f-1 progeny.

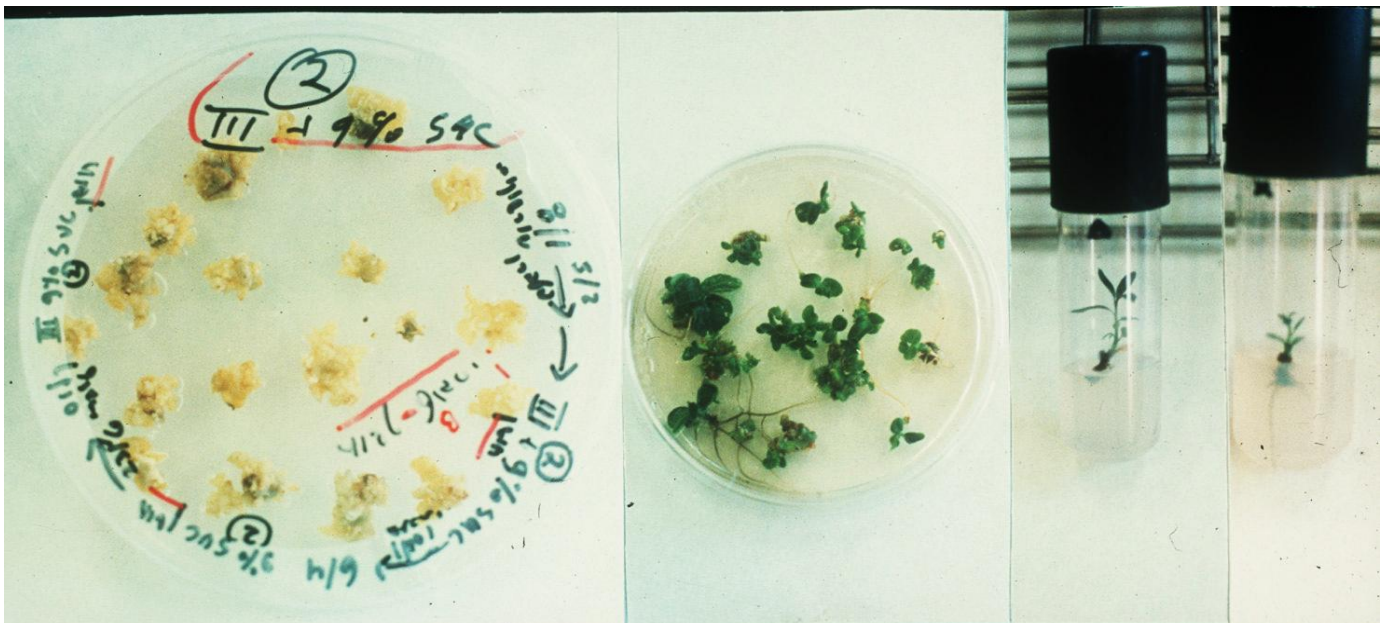

Figure 9. Methodology steps during genetic manipulation. 


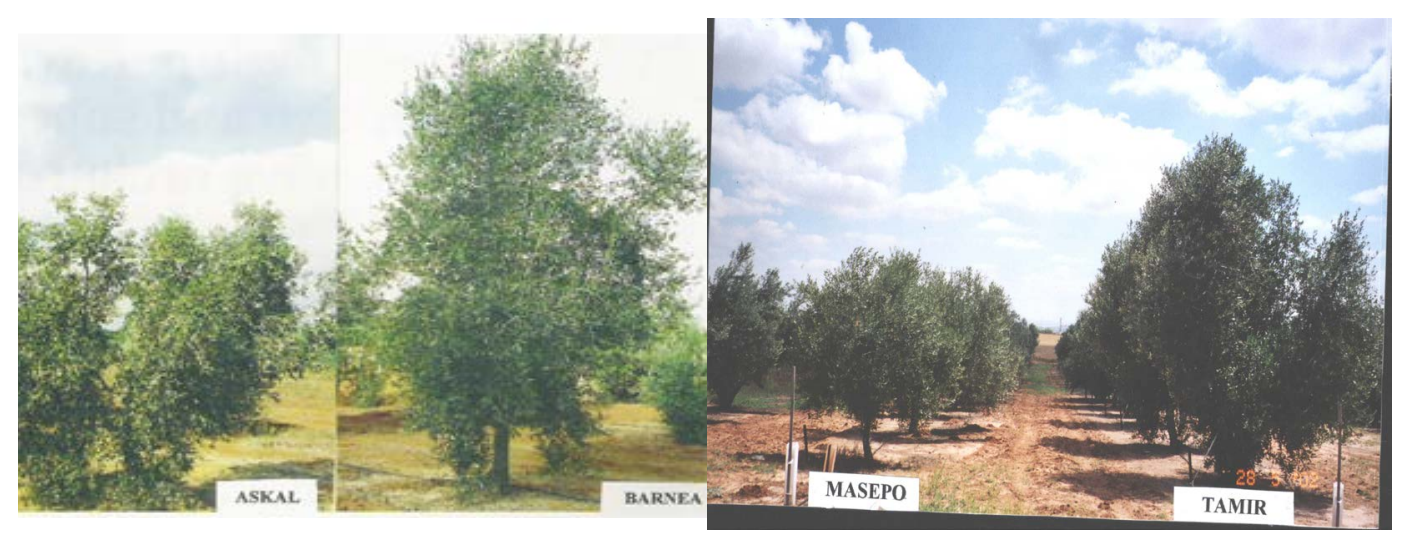

Figure 10. Four of Israeli varieties bred for specific table and oil orchards.

an integrated approach between the plant genetic properties of the available old and new cultivars combined with horticultural treatments and manipulations has to be undertaken in the new modern industrial olive groves [34] [35]. This genetic and molecular control of properties desired for specific growing conditions is still limited, partial and only just starting to become available [36] [37]. We anticipate that the present genomic research will lead in the near future to the information required for more rapid and efficient olive breeding, essential for a new intensive fully mechanized olive oil industry.

\section{References}

[1] Besnard, G., El Bakkali, A., Haouane, H., Baali-Cherif, D., Moukhli, A. and Khadari, B. (2013) Population Genetics of Mediterranean and Saharan Olives: Geographic Patterns of Differentiation and Evidence for Early Generations of Admixture. www.aob.oxfordjournals.org

[2] Lumaret, R. and Ouazzani, N. (2001) Ancient Wild Olives in Mediterranean Forest. Nature, 413, 700. http://dx.doi.org/10.1038/35099680

[3] Besnard, G., Khadari, B. and Navascues, M. (2013) The Complex History of the Olive Tree: From Late Quaternary Diversification of Mediterranean Lineages to Primary Domestication in Northern Levant. Proceedings of the Royal Society B: Biological Sciences, 280, 20122833. http://dx.doi.org/10.1098/rspb.2012.2833

[4] Kaniewski, D., Van Campo, E., Boiy, T., Torreal, J.F., Kharadari, B. and Besnard, G. (2012) Primary Domestication and Early Uses of the Emblematic Olive Tree: Palaeo-Botanical, Historical and Molecular Evidence from the Middle East. Biological Reviews, 87, 885-899. http://dx.doi.org/10.1111/j.1469-185X.2012.00229.x

[5] Lavee, S. (1992) Evolution of Cultivation Techniques in Olive Growing. Olive Oil Quality, Firenze, 37-44.

[6] Besnard, G. and Berville, A. (2000) Multiple Origin of Mediterranean Olive (Olea europaea L. ssp. europaea) Based upon Mitochondrial DNA Polymorphisms. Life Sciences, 323, 173-181.

[7] Belaj, A., Satowic, Z., Rallo, L. and Trojillo, I. (2002) Genetic Diversity and Relationships in Olive (Olea europaea L.) Germplasm Collection as Determined by Randomly Amplified Polymorphic DNA. Theoretical and Applied Genetics, 105, 638-644. http://dx.doi.org/10.1007/s00122-002-0981-6

[8] Belaj, A., Munoz-Diez, C., Baldoni, I., Satowic, Z. and Barranco, D. (2010) Genetic Diversity and Relationships of wild Cultivated Olives at Regional Level in Spain. Scientia Horticulturae, 124, 323-330. http://dx.doi.org/10.1016/j.scienta.2010.01.010

[9] Baldoni, L., Tosti, N., Ricciolini, C., Belaj, A., Pannelli, G., Gemana, M.A. and Mulas, M. (2006) Genetic Structure of Wild and Cultivated Olives in the Central Mediterranean Basin. Annals of Botany, 98, 935-942. http://dx.doi.org/10.1093/aob/mcl178

[10] Breton, C., Tersac, M. and Berville, A. (2006) Genetic Diversity and Gene Flow between the Wild Olive (Oleaster, Olea europaea L.) and the Olive: Several Pilo-Pleistocene Refuge Zones in the Mediterranean Basin Suggested by Simple Sequence Repeats Analysis. Journal of Biogeography, 33, 1916-1928. http://dx.doi.org/10.1111/j.1365-2699.2006.01544.x

[11] Diez, C.M., Imperato, A., Rallo, L., Baranco, D. and Trojillo, I. (2012) Worldwide Core Collection of Olive Cultivars Based on Simple Sequence Repeat and Morphological Markers. Crop Science, 52, 211-221. http://dx.doi.org/10.2135/cropsci2011.02.0110

[12] Angiolillo, A., Mencuccini, M. and Raldoni, I. (1999) Olive Genetic Diversity Assessed Using Amplified Fragments 
Length Polymorphisms. Theoretical and Applied Genetics, 98, 411-421. http://dx.doi.org/10.1007/s001220051087

[13] Lavee, S. (2011) The Revolutionary Impact of Introducing Irrigation-Intensification to the Olive Oil Industry. Acta Horticulturae, 888, 21-30.

[14] Lavee, S., Avidan, N., Haskal, A. and Ogrodovich, A. (1996) Juvenility Period Reduction in Olive Seedlings-A Tool for Enhancement of Breeding. Olivae, 60, 33-41.

[15] Moreno-Alías, I., López, R., Luque, F., Rapoport, H.F., Hammami, S., León, L. and De la Rosa, R. (2012) Overcoming Juvenility in an Olive Breeding Program. Acta Horticulturae, 949, 221-226.

[16] Kalif, M. and Trigi, A. (1984) Observations Preliminaries a Une Selection Clonal de la variete d'olivier Chemlali Olea. Oleae, 17, 183-185.

[17] Suarez, M.P., Lapez-Rivares, P., Cantero, M.L. and Orolovas, J. (1990) Clonal Selection on “Manzanilla de Sevilla”. Acta Horticulturae, 286, 117-119.

[18] Tous, J., Romero, A., Plana, J. and Aranburu, J. (1998) Selecci.n clonal de la variedad de olive “Arbequina”. Presentaci.n del clon IRTA-1-18. Phytoma, 102, 15-28.

[19] Bradly, M.V., Grrigs, W.H. and Hartmann, H.T. (1961) Studies on Self and Cross-Pollination of Olives under Varying Temperatures. California Agriculture, 15, 4-5.

[20] Mert, C., Barut, E. and Ipek, A. (2013) Quantitative Seasonal Cha Ges in the Leaf Phenolic Content Related to the Alternate-Bearing Patterns of (Olea europaea L. Gemelik). Journal of Agricultural Science and Technology, 15, 9951006.

[21] Lavee, S., Harshemesh, H. and Avidan, N. (1986) Phenolic Acids-Possible Involvement in Regulating Growth and Alternate Fruiting in Olive Trees. Acta Horticulturae, 179, 317-338.

[22] Baldoni, L., Pellagrini, A., Mencuccini, M., Angiolillo, A. and Mulas, M. (2000) Genetic Relationships among Cultivated and Wild Olives Revealed by AFLP Markers. Acta Horticulturae, 521, 275-284.

[23] Belaj, A., Munoz-Diez, C., Baldoni, L., Porceddu, A., Barranco, D. and Satovic, Z. (2007) Genetic Diversity and Population Structure of Wild Olives from the North-West Mediterranean Assessed by SSR Markers. Annals of Botany, 100, 449-458. http://dx.doi.org/10.1093/aob/mcm132

[24] Amane, M., Lumaret, R., Hany, V., Ouazzani, M., Debain, C., Vivier, G. and Deguilloux, M.F. (1999) Chloroplast-DNA Variation in Cultivated and Wild Olive (Olea europaea L.). Theoretical and Applied Genetics, 99, 133-139. http://dx.doi.org/10.1007/s001220051217

[25] Merkuria, G., Collins, G., Sedgley, M. and Lavee, S. (2001) Identification of Genetic Markers in Olive Linked to Olive Leaf Spot Resistance and Susceptibility. Journal of the American Society for Horticultural Science, 126, 305-308.

[26] Belaj A., Trujillo, I., De la Rosa, R. and Rallo, L. (1999) Selection of RAPD Markers for Cultivar Identification. Australian Olive Growers, 10, 27-28.

[27] Belaj, A., Satovic, Z., Rallo, L. and Trujillo, I. (2004) Optimal Use of RAPD Markers for Identifying Varieties in Olive (Olea europaea L.) Germplasm Collections. Journal of the American Society for Horticultural Science, 129, 266-270.

[28] Biton, I., Shevtsov, S., Ostersezer, O., Mani, Y., Lavee, S., Avidan, B. and Ben-Ari, G. (2012) Genetic Relationships and Hybrid Vigor in Olive (Olea europaea L.) by Microsatellites. Plant Breeding, 131, 767-774. http://dx.doi.org/10.1111/pbr.12001

[29] Ben Ari, G., Avidan, B., Biton, I., Mani, Y. and Lavee, S. (2014) The Diversity of Performance of Commercial Olive Clones Selected from the Autochthonous cv. Souri Population for Intensive Irrigated Cultivation. HortScience, 49, 425-429.

[30] Merkuria, G., Sedgley, M., Collins, G. and Lavee, S. (2002) Development of a Sequence-Tagged Site for the RAPD Marker Linked to Leaf Spot Resistance in Olive. Journal of the American Society for Horticultural Science, 127, 673676.

[31] Lavee, S. and Avidan, B. (2002) Olive Germplasm Development Past and Present Approaches for Genetic Improvement. Acta Horticulturae, 586, 47-56.

[32] Lavee, S. and Avidan, B. (2011) Heredity Diversity in Populations of Free-, Self- and Specific Cross-Pollinated Progenies of Some Olive (Olea europaea L.) Cultivars. Israel Journal of Plant Sciences, 59, 29-37. http://dx.doi.org/10.1560/IJPS.59.1.29

[33] Ferguson, L., Sibbitt, G.S. and Martin, G. (1994) Production Manual. No. 3353, Division of Agricultural Sciences, University of California, California.

[34] Smith, H.M. and Samach, A. (2013) Constrains to Obtaining Consistent Annual Yields in Perennial Tree Crops. I: Heavy Fruit Load Dominates over Vegetative Growth. Plant Science, 207, 156-167. http://dx.doi.org/10.1016/j.plantsci.2013.02.014 
[35] Samach, A. and Smith, H.M. (2013) Constrains to Obtaining Consistent Annual Yields in Perennial Tree Crops. II: Environment and Fruit Load Affect Induction of Flowering. Plant Science, 207, 168-176.

http://dx.doi.org/10.1016/j.plantsci.2013.02.006

[36] Lavee, S., Avidan, B. and Meni, Y. (2003) Askal, a New High Performing Oil Variety for Intensive and Supper-Intensive Olive Orchards. Olivae, 97, 53-59.

[37] Rallo, L., Barranco, D., De la Rosa, R. and Leon, L. (2008) Chiquitita Olive. HortScience, 43, 528-531. 
Scientific Research Publishing (SCIRP) is one of the largest Open Access journal publishers. It is currently publishing more than 200 open access, online, peer-reviewed journals covering a wide range of academic disciplines. SCIRP serves the worldwide academic communities and contributes to the progress and application of science with its publication.

Other selected journals from SCIRP are listed as below. Submit your manuscript to us via either submit@scirp.org or Online Submission Portal.
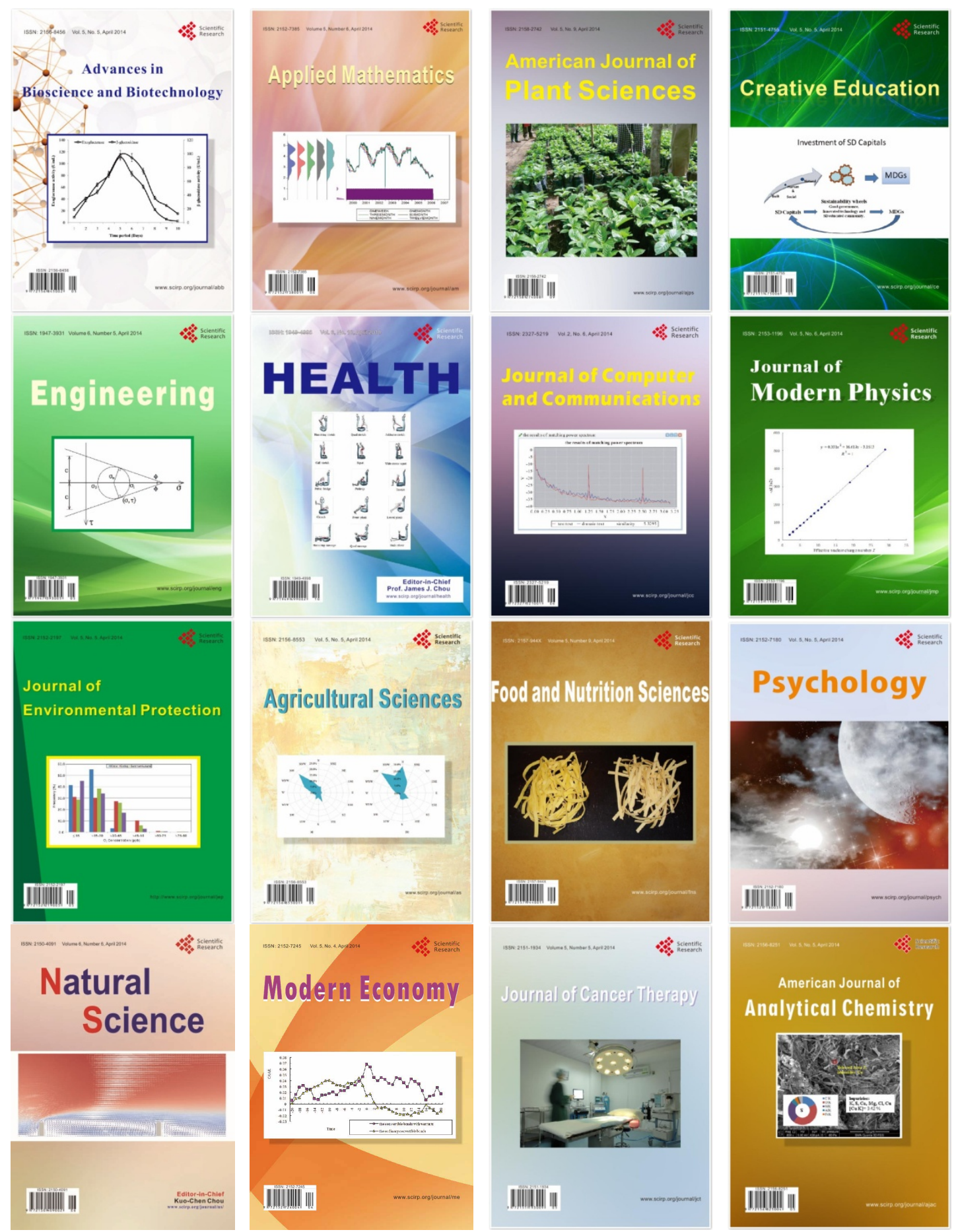